\title{
Application of Dynamic Temperature-Humidity Chamber for Measuring Moisture Sorption Isotherms of Biomaterials as Compared to the Conventional Isopiestic Method
}

\author{
Maha Al-Khalili (D, Nasser Al-Habsi, and Mohammad Shafiur Rahman \\ Department of Food Science and Nutrition, College of Agricultural and Marine Sciences, Sultan Qaboos University, P. O. Box 34- \\ 123, Al-Khod 123, Oman \\ Correspondence should be addressed to Maha Al-Khalili; mahaalikh@gmail.com
}

Received 31 August 2021; Revised 4 November 2021; Accepted 12 November 2021; Published 30 December 2021

Academic Editor: Ming Hua

Copyright () 2021 Maha Al-Khalili et al. This is an open access article distributed under the Creative Commons Attribution License, which permits unrestricted use, distribution, and reproduction in any medium, provided the original work is properly cited.

\begin{abstract}
Measurement of water activity and moisture sorption isotherms of foods and biomaterials are important to determine the state of water. In this work, a dynamic temperature-humidity (DTH) controlled chamber was used to measure water sorption isotherm and compared with the conventional isopiestic method. Temperature and relative humidity of DTH chamber can be controlled in the range of -15 to $100^{\circ} \mathrm{C}$ and 0 to $98 \%$, respectively; thus, measurement of water activity at any point can be measured within the above ranges. The DTH chamber method showed high reproducibility as compared with the conventional isopiestic method when measured isotherms of cellulose, lignin, and hemicellulase were compared at $30^{\circ} \mathrm{C}$. Finally, isotherm data of cellulose, lignin, and hemicellulase were generated in the temperature range of $10-90^{\circ} \mathrm{C}$ using DTH chamber, and these were modelled by BET and GAB equations. The model parameters were correlated with the temperature.
\end{abstract}

\section{Introduction}

Water activity indicates the states of water in foods, and it is a crucial indicator of food stability [1-4]. Moisture sorption isotherm at a certain temperature indicates the relationship of the water activity and moisture content. Water activity of a food is primarily a tool to assess the microbial growth, rancidity, nonenzymatic and enzymatic reactions, vitamin losses, and textural attributes [5-9].

The conventional static isopiestic method uses desiccator (i.e., an enclosed atmospheric environment of a specific relative humidity) and saturated salt solutions (i.e., creating specific relative humidity environments). It is the most basic and popular method, and it is widely used to measure moisture sorption isotherm of foods. The isopiestic method has been developed by Bousfield, and it is defined as the transport of solvent from a solution with higher vapor pressure to a solution with lower vapor pressure [10]. The principle of isopiestic method mainly relays on the creation of humid environment in an air tight closed desiccator at a constant temperature $[8,11,12]$. Initially, desiccator was commonly used, and then, different types of cells, such as glass and metal jars, and plastic containers were also used. It is a simple method and needs a simple setup (i.e., a desiccator or air tight chamber, different types of salts, and sample holder) [13]. Temperatures of the jars or cells with sample and saturated salt solutions are mainly controlled by placing these in water bath or air oven. The long equilibration time of several weeks to months is one of the major issues of this method [13-16]. The maintenance of the saturated salt solution plays an important role in maintaining specific relative humidity in the chamber [14]. A layer of salt crystals needs to be maintained to ensure saturated condition of the salt solution during whole equilibrium time. However, salts should be a soft mixture, and it is important to avoid fossil formation (i.e., rock like mass) $[16,17]$. In order to check the equilibrium condition of the sample and environment in the desiccator, it needs to be opened and closed time to time. This breaks the equilibrium relative humidity in the desiccator, and it needs time to reach at the set specific 
relative humidity after reclosing the desiccator. Samples and salts are susceptible for microbial growth during the long equilibrium period, especially at high water activity $[13,18,19]$. In order to control the microbial growth, thymol and other chemicals (e.g., toluene) in a small beaker are placed inside the desiccator; however, these are toxic and hazardous.

Over the years, a wide range of isopiestic setups with improved designs were reported in the literature. The jars with evacuated system (i.e., under vacuum) were then introduced to enhance the equilibrium time [19-21]. It can equilibrate samples faster and act as thermal insulation; however, it is higher in cost due to its construction and required additional instruments. Another improvement was performed by placing an in situ balance to record mass without opening and closing the jars or chambers. This could avoid the disruption of equilibrium atmosphere by avoiding the opening and closing of jar [11,22].

An apparatus of circulating air chamber was also developed earlier. It consists of equilibrium chamber, magnetic stirrer for air circulation, and an in situ sensitive balance to record the mass. The complete setup was then placed in a constant temperature bath [11, 23, 24]. Gal. [20] used a system to create air with specific relative humidity, and then, air is supplied to the isotherm measurement chamber. The air humidity was controlled either by cooling air to condense out water or high pressure air was expanded in a chamber. Recently, commercial Dynamic Vapor Sorption (DVS) systems are being used, and it is built with a temperaturehumidity controlled chamber and an in-build microbalance. The relative humidity of the chamber was maintained by circulating nitrogen gas at a specific relative humidity. In this system, moisture was sprayed over dry nitrogen gas in a separate chamber to attain a specific relative humidity before circulating it into the isotherm chamber $[13,25]$. In this case, opening and closing of the chamber can be avoided. Rapid equilibrium was the main advantage of this method, and the same sample can be used for entire isotherm measurement (i.e., complete water activity range). A very small sample needs to be used (i.e., microgram) in the DVS system. However, complete DVS system is very costly.

Isotherms of spray dried tomato pulp, texturized soy protein, hazelnut, rice, barley malt, cookies, and crackers were investigated within a narrow range of temperature, mainly $20-60^{\circ} \mathrm{C}$ [26-34]. In the literature, isotherm data of foods within a wide range of temperature (i.e., chilled condition and above $60^{\circ} \mathrm{C}$ ) are limited. Sorption isotherms of cellulose and lignin were reported by Mihranyan et al. [35] and Volkova et al. [36]. However, limited data are presented for hemicellulase. In this study, these materials were used to test the proposed dynamic temperature-humidity (DTH) chamber for measuring moisture sorption isotherm and to develop their prediction models.

According to the literature, more than 200 different equations have been developed to shape the sorption isotherms at different temperature [37]. Some of these models relay on the theoretical basis, while others are considered as semiempirical or empirical $[26,30,38]$. The GAB (Guggenheim-Anderson-de Boer) and BET (Brunauer-
Emmett-Teller) are the most commonly used models for the prediction of the sorption isotherms of different foods [39-41]. This is mainly due to their theoretical basis, and model parameters have physical meaning.

At present, different types of temperature-humidity controlled chambers are commercially available and these could be used to measure the water sorption isotherm. The objective of this study was to use a dynamic temperaturehumidity (DTH) controlled chamber for measuring water sorption isotherms of foods. The adsorption isotherms of cellulose, lignin, and hemicellulase were measured by DTH chamber, and these isotherms were compared with the conventional isopiestic method (i.e., $30^{\circ} \mathrm{C}$ ). In addition, isotherm data were generated in the temperature range of 10$90^{\circ} \mathrm{C}$ using $\mathrm{DTH}$ chamber, and these were modelled by BET and GAB equations.

\section{Materials and Methods}

2.1. Materials. Commercial cellulose $(\mathrm{C} 6 \mathrm{H} 10 \mathrm{O} 5)_{\mathrm{n}}$, lignin $\left(\mathrm{C}_{81} \mathrm{H}_{92} \mathrm{O}_{28}\right)$, and hemicellulase ( $\beta$-(1-4)-D-xylopyranosyl) were purchased from Sigma-Aldrich, USA. Seven saturated salt solutions, namely, lithium chloride $(\mathrm{LiCl})$, magnesium chloride $\left(\mathrm{MgCl}_{2}\right)$, magnesium nitrate $\left(\mathrm{Mg}\left(\mathrm{NO}_{3}\right)_{2}\right)$, sodium bromide $(\mathrm{NaBr})$, strontium chloride $\left(\mathrm{SrCl}_{2}\right)$, potassium chloride $(\mathrm{KCl})$, and potassium nitrate $\left(\mathrm{KNO}_{3}\right)$, were used to create relative humidity environments: $11.5,32.7,52.9$, 57.7, 70.8, 84.3, and 95.0\%, respectively. Water activity values for these saturated salt solutions were obtained from Rahman [8]. In the conventional isopiestic method, thymol was used to overcome the microbial growth in the samples and saturated salt solutions.

2.2. Moisture Content. Moisture content of the sample was measured in triplicates by drying samples at $70^{\circ} \mathrm{C}$ for $18 \mathrm{~h}$ in a vacuum oven at pressure $10 \mathrm{kPa}$ (VD 23, Binder, Germany).

2.3. Conventional Isopiestic Method. Sample $(0.2 \mathrm{~g})$ in a glass dish was placed inside a tightly closed glass jar, which was maintained at a specific relative humidity. The specific relative of the jar was created by placing a saturated salt solution in a beaker. Seven saturated salt solutions as mentioned in the earlier section were used to create relative humidity. A layer of salts at the bottom of the beaker was maintained during the whole equilibrium period to ensure the saturated condition of the salt solutions. Thymol in a $5 \mathrm{ml}$ beaker was placed inside the jar to avoid any microbial growth in the sample or solution. Jars containing samples, saturated salt solutions, and thymol were kept in an oven (Gallenkamp, UK; model: 300 plus series) at $30^{\circ} \mathrm{C}$, and mass of the sample in each jar was recoded every two days until a constant weight was achieved.

2.4. Dynamic Temperature-Humidity Chamber. In this proposed method, a dynamic temperature-humidity (DTH) chamber (Model 240, Binder, Germany) was used to measure the sorption isotherm. A schematic diagram of the DTH is shown in Figure 1. DTH chamber applies APT-line $^{\mathrm{TM}}$ technology to maintain homogeneous climate 


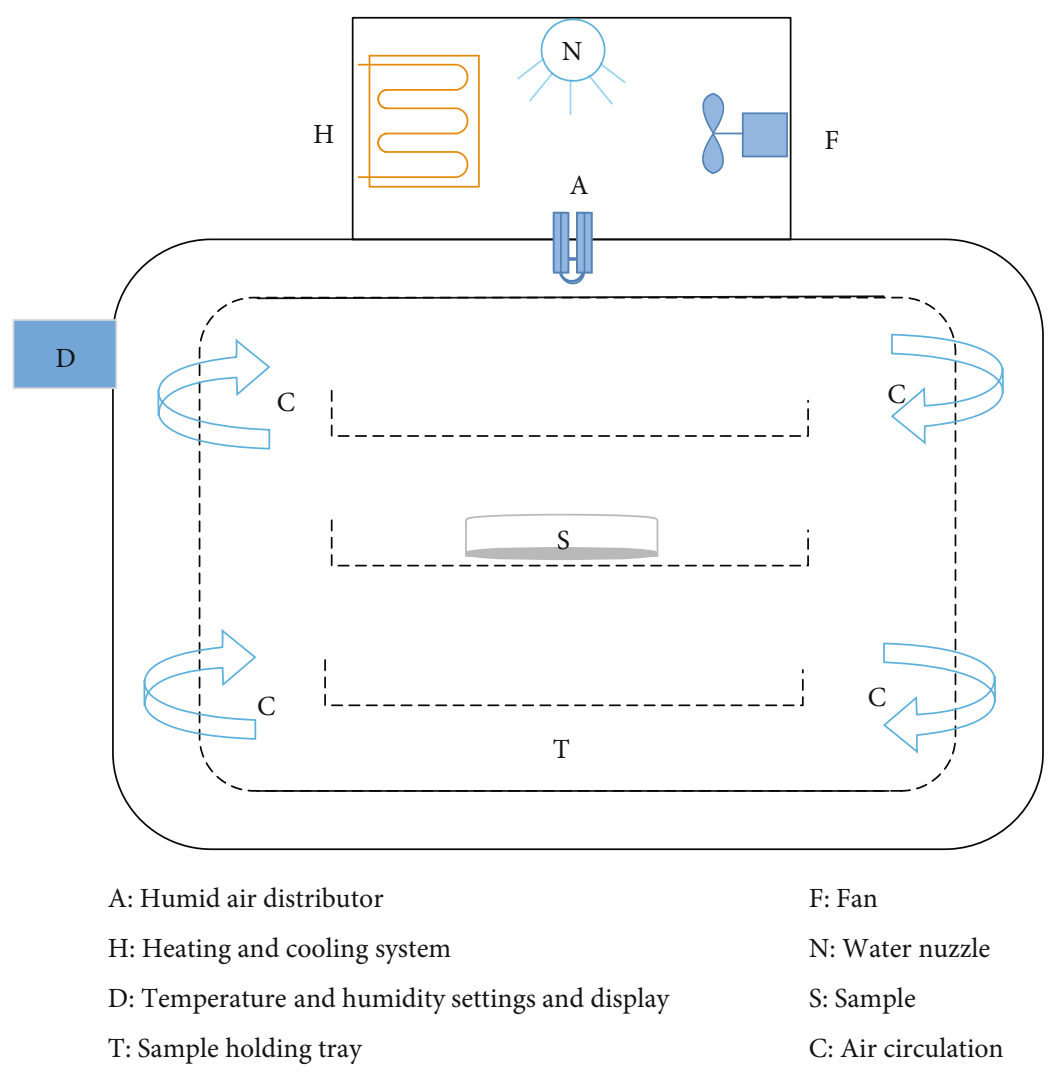

Figure 1: Schematic diagram of the dynamic temperature-humidity (DTH) chamber.

conditions. It stands for "Advanced Preheating Technology" and a unique heating system that ensures homogeneous air and temperature distribution inside a chamber. Its controller allows it to operate in the condensation free region and special air flow (i.e., turbine) to ensure high level of temperature homogeneity, short heating up time, and rapid heat transfer. At the same time, this technology also ensures fast recovery of the humidity and temperature after opening and closing [42]. In this technology, water spray in a premixing chamber and mix with air (i.e., desire relative humidity) and then circulate to the humidity chamber at a specified relative humidity. The air relative humidity and temperature are automatically controlled by the system. The temperature and humidity of the chamber can be controlled in the range of -15 to $100^{\circ} \mathrm{C}$ and 0 to $98 \%$, respectively. The temperature of the chamber was maintained with a thermostat, and humidity was maintained at a desired level by automatic water spray through a nozzle.

\subsection{Dynamic Temperature-Humidity (DTH) Chamber Method}

2.5.1. Initial Conditioning. Sample $(0.2 \mathrm{~g})$ was placed uniformly in a glass dish, and it was then conditioned in the DTH chamber, which was set at $30^{\circ} \mathrm{C}$ and $5 \%$ relative humidity. Weight of the sample was recorded until $60 \mathrm{~min}$, initially every $5 \mathrm{~min}$ and then every $10 \mathrm{~min}$. This procedure was used to bring the sample at the start of the adsorption isotherm. Triplicate samples were used in this procedure.
The adsorption data was fitted to the Weibull equation to determine actual equilibrium moisture. Weibull equation can be written as follows:

$$
\frac{M_{w}-M_{e}}{M_{o}-M_{e}}=\exp \left(-\frac{t}{\beta}\right)^{\alpha}
$$

where $M_{o}, M_{w}$, and $M_{e}$ are the moisture at initial, time $t$, and equilibrium ( $\mathrm{g} / 100$ dry-solids), respectively, $t$ is the time (min), and $\alpha$ and $\beta$ are the model parameters. The data was fitted to Equation (1) using the NLREG software, and model parameters were determined [43]. The moisture after $30 \mathrm{~min}$ was compared with the equilibrium moisture as determined from the Weibull equation.

2.5.2. Equilibration Time Determination. Required equilibrium time at each step increase in humidity (i.e., 10\% RH) was determined by measuring adsorption kinetics by changing relative humidity from 5 to $15 \%$ (i.e., $10 \%$ increase in relative humidity). In this procedure, weight of the sample was recorded after changing relative humidity from 5 to $15 \%$, initially every $5 \mathrm{~min}$ and then every $10 \mathrm{~min}$. Samples were used in triplicates.

2.5.3. Isotherm Measurement. First, DTH chamber was set at $30^{\circ} \mathrm{C}$ and $5 \%$ relative humidity and started the experiment after it was reached at the set condition. Samples $(0.2 \mathrm{~g})$ were placed uniformly in three glass dishes, and these were placed inside the DTH chamber. These were then conditioned for 


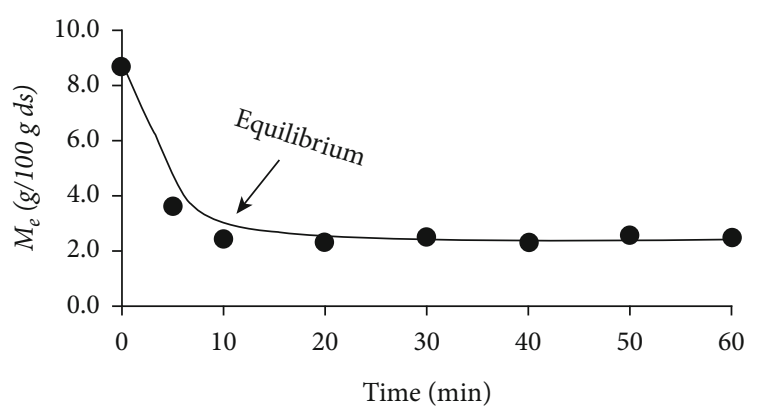

(a)

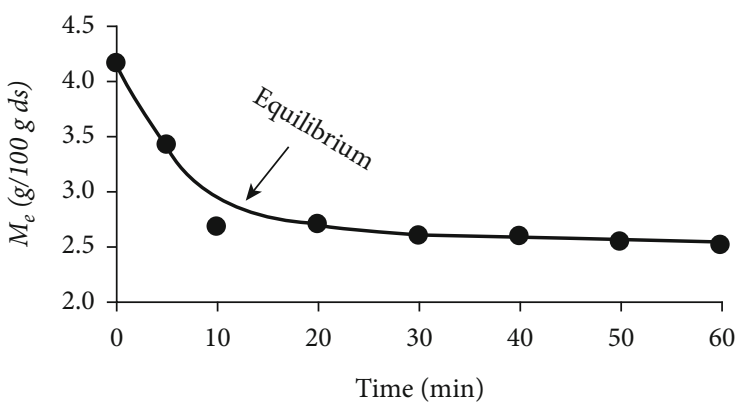

(b)

Time (min)

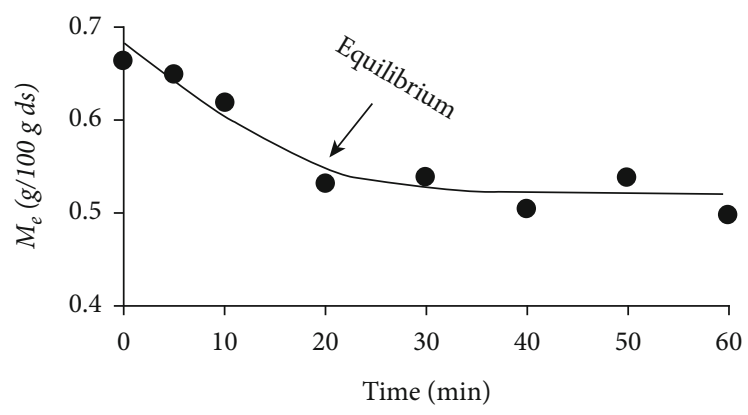

(c)

FIGURE 2: Sorption kinetics of the dried samples for initial conditioning before starting the adsorption isotherm ((a) cellulose, (b) lignin, and (c) hemicellulase).

$30 \mathrm{~min}$, and the weight was recorded. The relative humidity of the DTH chamber was then set to $10 \%$ relative humidity, and weight of the sample was recorded after $30 \mathrm{~min}$. The same procedure was followed after changing the relative humidity of the chamber at $10 \%$ increment up to $90 \%$ relative humidity. Finally, DTH chamber was set at $95 \%$ relative humidity. The same procedures were repeated for other isotherm measurement at different temperatures (i.e., 10, 30, 50, 70 , and $\left.90^{\circ} \mathrm{C}\right)$.

2.6. Isotherm Models. Moisture adsorption isotherms were modelled by commonly used fundamental BET and GAB equations. BET equation can be written as follows [44]:

$$
M_{e}=\frac{M_{b} B a_{w}}{\left[\left(1-a_{w}\right)\left(1+(B-1) a_{w}\right)\right]},
$$

where $M_{e}$ and $M_{b}$ are the equilibrium moisture and BET monolayer moisture contents (dry basis: g water/100 g dry solids) and $B$ is a constant related to the net heat of sorption. The BET isotherm is valid up to water activity 0.45 , and it would be enough to determine the parameters $M_{b}$ and $B$ [45]. BET parameters were estimated graphically by plotting $\left[a_{w} /\left(1-a_{w}\right) M_{w}\right]$ versus water activity within water activity 0.45 . The values of $B$ and $M_{b}$ were estimated from the slope $\left[(B-1) / M_{b} B\right]$ and intercept $\left[1 / M_{b} B\right]$ of the best fitted line.

$\mathrm{GAB}$ equation was used to model the isotherm data from water activity 0.05 to 0.95 . The GAB model was modified from BET equation considering multilayer sorption, and it is the extended isotherm considering water activity beyond 0.45 [46]. This modified equation was treated kinetically by DeBoer [47] and statically by Guggenheim [48], and it was then known as GAB equation. It is one of the most widely used models in the food domains. GAB equation can be written as follows:

$$
M_{e}=\frac{M_{g} C K a_{w}}{\left[\left(1-K a_{w}\right)\left(1-K a_{w}+C K a_{w}\right)\right]},
$$

where $M_{g}$ is the GAB monolayer moisture content (dry basis, $\mathrm{g} / 100 \mathrm{~g}$ dry solids), $C$ is a constant related to the monolayer heat of sorption, and $K$ is a factor related to the heat of sorption of multilayer.

Clausius-Clapeyron equation was used to calculate the isosteric heat of adsorption [49]:

$$
\frac{d\left(\left[\ln \left(a_{w}\right)\right]\right)}{d(1 / T)}=-\left(\frac{Q_{s}}{T}\right)
$$

where $a_{w}$ is the water activity, $T$ is temperature $(K), Q_{s}$ is the net isosteric heat of sorption $(\mathrm{kJ} / \mathrm{kg})$. It can be defined as the energy required to remove a unit mass of adsorpted water at a specific temperature [50]. The net isosteric heat of sorption $\left(Q_{s}\right)$ was estimated from the slope of $\ln \left(a_{w}\right)$ versus $1 / T$ plots at a specific moisture content, and it can be estimated at each temperature [51]. 
TABLE 1: BET and GAB models' parameters for commercial fibers and the enzyme hemicellulase.

\begin{tabular}{|c|c|c|c|c|c|c|c|c|c|}
\hline \multirow{2}{*}{ Sample } & \multirow{2}{*}{$\begin{array}{c}X_{w} \\
(\mathrm{~g} / 100 \mathrm{~g})\end{array}$} & \multicolumn{4}{|c|}{ BET model parameters } & \multicolumn{4}{|c|}{ GAB model parameters } \\
\hline & & $T\left({ }^{\circ} \mathrm{C}\right)$ & $M_{b}$ (g/100 g dry solids) & $B$ & $R^{2}$ & $M_{g}$ (g/100 g dry solids) & $C$ & $K$ & $R^{2}$ \\
\hline \multirow{5}{*}{ Cellulose } & \multirow{5}{*}{8.0} & 10 & 6.37 & 120.69 & 0.98 & 8.30 & 106.83 & 0.57 & 0.99 \\
\hline & & 30 & 4.82 & 25.91 & 0.99 & 5.83 & 23.09 & 0.72 & 0.99 \\
\hline & & 50 & 4.26 & 4.09 & 0.97 & 4.30 & 7.13 & 0.77 & 0.99 \\
\hline & & 70 & 1.42 & 4.55 & 0.99 & 3.00 & 5.00 & 0.39 & 0.97 \\
\hline & & 90 & 1.54 & 1.67 & 0.99 & 2.50 & 1.00 & 0.76 & 0.97 \\
\hline \multirow{5}{*}{ Lignin } & \multirow{5}{*}{3.9} & 10 & 7.28 & 196.14 & 0.99 & 8.00 & 400.00 & 0.87 & 0.99 \\
\hline & & 30 & 6.07 & 412.00 & 0.99 & 6.26 & 200.00 & 0.95 & 0.99 \\
\hline & & 50 & 5.68 & 70.44 & 0.99 & 5.88 & 60.00 & 0.95 & 0.85 \\
\hline & & 70 & 3.74 & 41.17 & 0.99 & 3.78 & 40.00 & 0.98 & 0.88 \\
\hline & & 90 & 2.20 & 20.22 & 0.99 & 2.52 & 20.00 & 0.99 & 0.96 \\
\hline \multirow{5}{*}{ Hemicellulase } & \multirow{5}{*}{0.7} & 10 & 3.98 & 9.65 & 0.99 & 4.75 & 10.00 & 0.72 & 0.99 \\
\hline & & 30 & 4.39 & 6.78 & 0.99 & 4.85 & 7.12 & 0.82 & 0.99 \\
\hline & & 50 & 3.21 & 4.25 & 0.99 & 3.39 & 4.38 & 0.91 & 0.99 \\
\hline & & 70 & 2.09 & 3.33 & 0.99 & 2.50 & 3.25 & 0.83 & 0.99 \\
\hline & & 90 & 1.31 & 1.40 & 0.99 & 1.70 & 1.22 & 0.88 & 0.99 \\
\hline
\end{tabular}

$X_{w}$ : initial moisture content $(\mathrm{g} / 100 \mathrm{~g}$ sample).

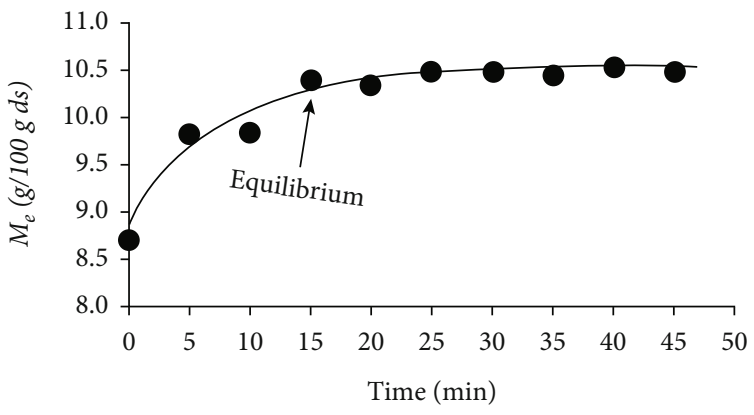

(a)

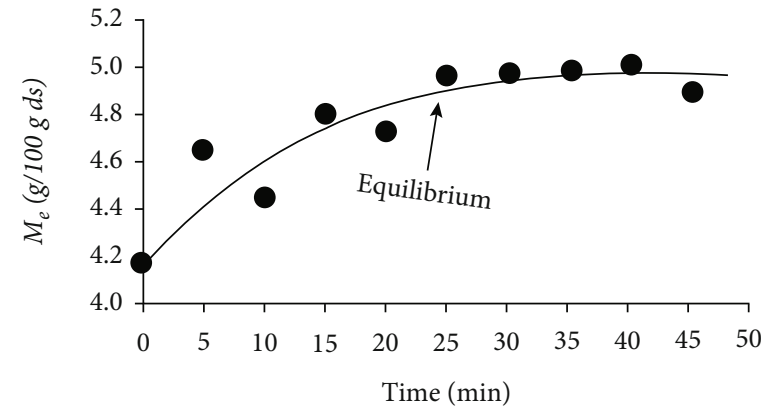

(b)

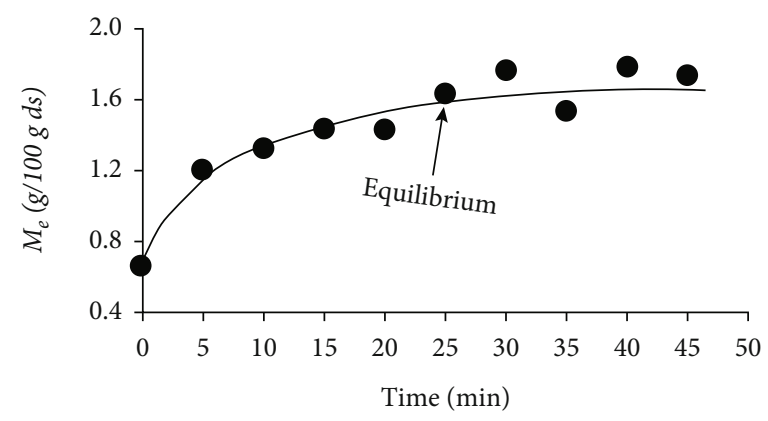

(c)

Figure 3: Adsorption kinetics of the dried samples at $15 \%$ relative humidity at $30^{\circ} \mathrm{C}((\mathrm{a})$ cellulose, (b) lignin, and (c) hemicellulase).

2.7. Statistical Analysis. Data are presented as average and standard deviation. Reproducibility of the measurement by each method was determined from the standard deviation divided by average value, and it was presented as percent. Nonlinear regression was used to predict the GAB model parameters, and the NLREG software was used (Sherrod, 1991). Accuracy of the models was evaluated considering regression coefficient, $R^{2}$.

\section{Results and Discussion}

3.1. Adsorption Kinetics. Figure 2 illustrates the initial conditioning of a sample at $30^{\circ} \mathrm{C}$ and $5 \%$ relative humidity. The initial moisture contents of cellulose, lignin, and hemicellulase were $8.0,3.9$, and $0.7 \mathrm{~g} / 100 \mathrm{~g}$ sample, respectively (Table 1). In the case of cellulose, Figure 2(a) shows a sharp decrease of moisture content as a function of time and after 


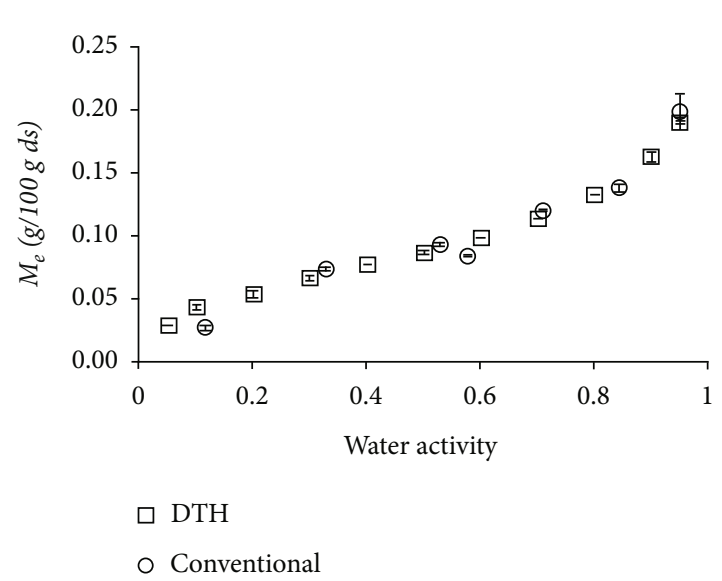

(a)

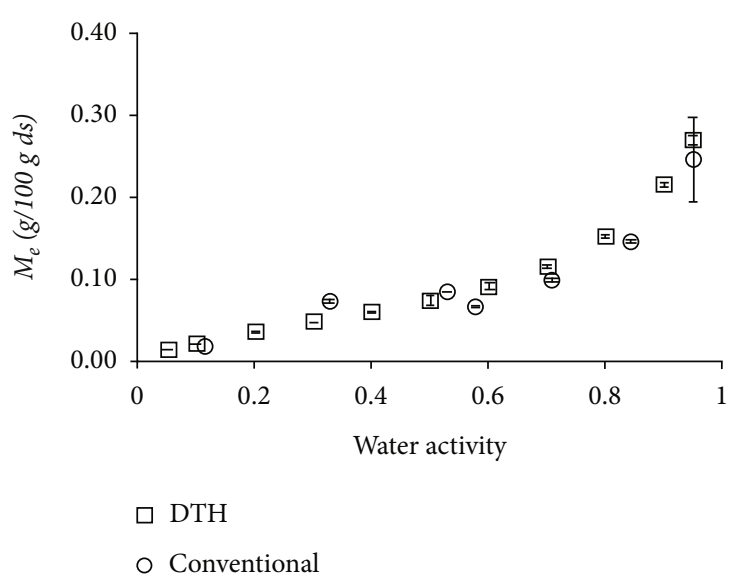

(b)

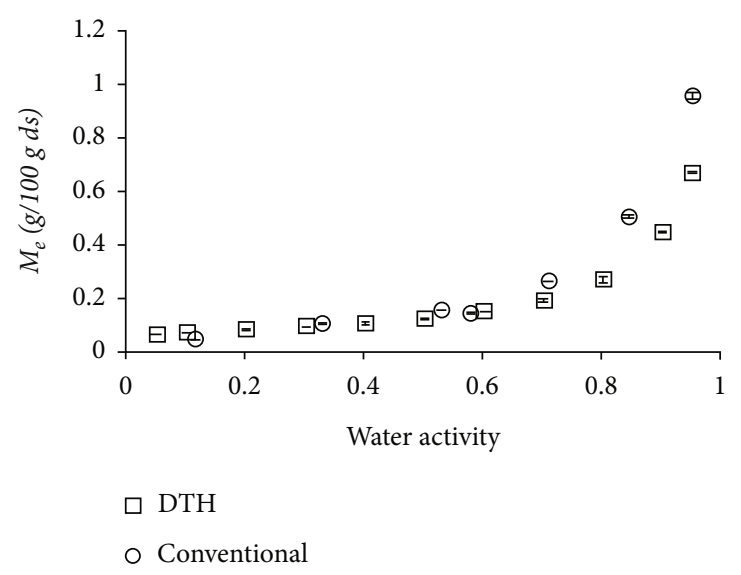

(c)

FIGURE 4: Adsorption isotherms as measured by DTH chamber and conventional isopiestic method ((a) cellulose, (b) lignin, and (c) hemicellulase).

10 min, moisture remained nearly constant. Similar change was also observed in the case of lignin, and moisture content was also remained nearly the same after $10 \mathrm{~min}$ (Figure 2(b)). In the case of hemicellullase, moisture content remained the same after $20 \mathrm{~min}$ (Figure 2(c)), since it was already contained very low moisture (i.e., low driving force for moisture adsorption). This indicated that the initial moisture content played a role to achieve the required equilibration time to reach initial conditioning. Tereshchenko [16] also identified that initial water activity (i.e., moisture) of a sample indicated the required equilibrium time. The moisture adsorption as a function of time was fitted to the Weibull equation, and moisture after $30 \mathrm{~min}$ and equilibrium moisture from the Weibull equation were determined. The percent deviation was observed below $0.14 \%$ when cellulose, lignin, and hemicellulase were considered. Therefore, $30 \mathrm{~min}$ was considered as the equilibration time.

Figure 3 shows the moisture adsorption kinetics at $30^{\circ} \mathrm{C}$, when relative humidity of the chamber was changed from the condition $5 \%$ to $15 \%$ (i.e., $10 \%$ increment). It shows that moisture increased exponentially and then reached to equilibrium. This shows that $30 \mathrm{~min}$ equilibration time was enough to reach equilibrium state for all 3 samples. However, in the case of isopiestic method, the equilibration time was observed more than 3 weeks at each relative humidity. Similarly, reported literature shows that the conventional isopiestic method took long equilibration time. In many instances, it took more than 4 weeks $[26,29,30,52]$.

\subsection{Comparison between Isopiestic and Controlled Humidity} Chamber Methods. Moisture adsorption isotherms as measured by DTH chamber and conventional method are shown in Figure 4 . The measured values by both methods were correlated, and $R^{2}$ were observed as $0.95,0.96$, and 0.91 , respectively, for cellulose, lignin, and hemicellulase. The reproducibility of the DTH and conventional methods varied from 0.0074 to $7.6 \%$ and 0.75 to $21 \%$, respectively, considering different equilibrium relative humidity used in this experiment. In addition, data points in the conventional method showed more random considering the whole trend of the curve as compared to DTH methods (i.e., DTH isotherm followed a smooth curve if the points are joined). This could be due to the fact that the DTH method used the same sample to measure adsorption isotherm for all relative humidity condition, while conventional method used different sample at each relative humidity. In addition, in the case of conventional method, physicochemical properties of the samples could be changed when stored for 3 weeks inside 
the glass jar, and more variability of the relative humidity (i.e., created by saturated salt solutions) and temperature in the glass jar could exist. Moreover, DTH chamber had the ability to maintain precise control of the relative humidity in the temperature-humidity chamber due to dynamic air circulation as compared to the static air in the conventional isopiestic chamber.

\subsection{Advantages of the Dynamic Temperature-Humidity} (DTH) Chamber. The main advantage of DTH was the shorter equilibrium time, as discussed in the earlier section. Faster equilibration was observed in the DTH chamber as compared to the conventional isopiestic method although $0.2 \mathrm{~g}$ was used in both methods. It was due to the mechanical air circulation used in the DTH, which accelerated the mass transfer. In addition, DTH chamber did not open during the specific equilibration experiment, while conventional ones needed to open and close time to time in order to check the mass (i.e., it took long time to attain again to the desire relative humidity). In addition, the required longer equilibrium time by conventional method can change the physical and chemical characteristics of the sample, especially at high water activity [8]. For example, in the case of lignin at high water activity, conventional method showed much higher water adsorption as compared to the DTH method (Figure 4). This could be due to the transformation of physicochemical changes occurred in lignin at high relative humidity for longer equilibrium time.

In the case of conventional method, specific salt is required to maintain a specific relative humidity [53-56]. Therefore, salts for all relative humidity values are required. However, salts for all relative humidity may not be readily available, and this could restrict the conventional method for all relative humidity conditions. In addition, any incremental level of relative humidity within 0 to $0.98 \%$ and temperature within -15 to $100^{\circ} \mathrm{C}$ can be achieved in the case of DTH chamber. In the case of conventional method, oven or water bath needs to be used for longer period (i.e., more than 4 weeks) $[13,18,19]$. This needs more energy consumption by the oven, and oven would be unable to use for other purposes.

In the conventional method, it is important to monitor the saturated conditions (i.e., a layer of deposited salt at the bottom) of the salt solution during complete experimental period to ensure a constant relative humidity [16]. In the process of moisture desorption from the sample (i.e., high moisture sample), salts can be dissolved over time and saturation could not be maintained. This needs the addition of salts time to time [56]. In addition, fossilization of salts could deviate the desired relative humidity [13]. Contamination of salts from the sample could also affect the desired relative humidity. In the proposed DTH method, all these issues could be avoided.

In the DTH method, there is no need to check equilibrium conditions time to time by opening and closing the chamber. In this case, weight of the sample needs to be taken after predetermined equilibrium time of $30 \mathrm{~min}$ (i.e., at each relative humidity). Metal cells, used at higher temperature, could be susceptible to corrosion $[24,57]$. Replacing metal cells with glass could be a favourable choice to overcome these issues, but it limits the isotherm measurement at lower temperatures [58-61]. In conventional method, handling of 9 to 10 cells for more than 4 weeks needs lots of handling time, whereas in the case of DTH chamber, minimal handling of the samples is required. In addition, lots of space is required for handling 9 to 10 jars in the case of conventional method. In the case of the DTH method, the same sample could be used for measuring water activity within the complete range of 0.05 to 0.98 relative humidity.

3.4. Water Adsorption Isotherm. Figure 5 show the measured adsorption isotherms of cellulose, lignin, and hemicellulase using DTH chamber and predicted model by GAB equation at different temperatures $\left(10,30,50,70\right.$, and $\left.90^{\circ} \mathrm{C}\right)$. Isotherms showed sigmoid shape, as observed and reported in the literature for foods $[13,38,39,52,62,63]$. In cases of lignin and hemicellulase, a sharp increase was observed after water activity 0.8 , indicating more swelling with the adsorption of water as compared to the cellulose. These isotherms shifted down as a function of increasing temperature from 10 to $90^{\circ} \mathrm{C}$. This was due to the increase of escaping tendency of water molecule at higher temperature [62]. Kapsalis [64] pointed that temperature affects the mobility of water molecules and enhanced dynamic equilibrium between water vapor and adsorbed phases. Similar observations were also stated for starchy foods $[27,65,66]$. Literature isotherms were mainly reported within $20-60^{\circ} \mathrm{C}$; however, the DTH chamber method can be used to measure isotherm up to $100^{\circ} \mathrm{C}$ as well as chilled conditions up to $-15^{\circ} \mathrm{C}$. This could be one of the major advantage of the proposed DTH method.

The measured absorption isotherm data of the three samples were fitted linearly with the BET model (Equation (2)) up to water activity 0.4 , and the regression coefficients $\left(R^{2}\right)$ were varied from 0.97 to 0.99 . The model parameters are shown in Table 1. The BET monolayer values of $M_{b}$ exhibited a decreasing trend with increasing temperature for all samples (i.e., $R^{2} 0.920,0.882$, and 0.961 for cellulose, lignin, and hemicellulase, respectively) (Figures 6(a)-6(c)). The decrease in $M_{b}$ could be due to the chemical and physical changes induced by elevated temperature [67]. Similar findings were also reported for rice, barley malt, cookies, and crackers $[27,28,32]$. The prediction of $M_{b}$ values is crucial since deterioration of foods is minimal at $M_{b}$ (i.e., strongly bound water cannot be involved in any deteriorative reaction either as solvent or as one of the substrates) [68]. The BET monolayer is an effective method that estimates the amount of bound water to specific polar sites in dehydrated food systems.

At $10^{\circ} \mathrm{C}, B$ values were $120.7,196.1$, and $9.7 \mathrm{~J} / \mathrm{g}$, respectively, in the cases of cellulose, lignin, and hemicellulase (Table 1$)$. The $B$ values were observed as $502.8 \mathrm{~J} / \mathrm{g}\left(22^{\circ} \mathrm{C}\right)$ for the corn flour [69], 101.5 and $5.7 \mathrm{~J} / \mathrm{g}$ for blueberries in the case of desorption and adsorption isotherms at $40^{\circ} \mathrm{C}$, respectively [70], $7.4 \mathrm{~J} / \mathrm{g}$ in the desorption isotherm and $9.2 \mathrm{~J} / \mathrm{g}$ in the adsorption isotherm at $30^{\circ} \mathrm{C}$ for dried potato [31], and $2.9 \mathrm{~J} / \mathrm{g}$ at $45^{\circ} \mathrm{C}$ for yams [34]. The heat of adsorption (i.e., $B$ ) showed a decreasing trend as a function of 


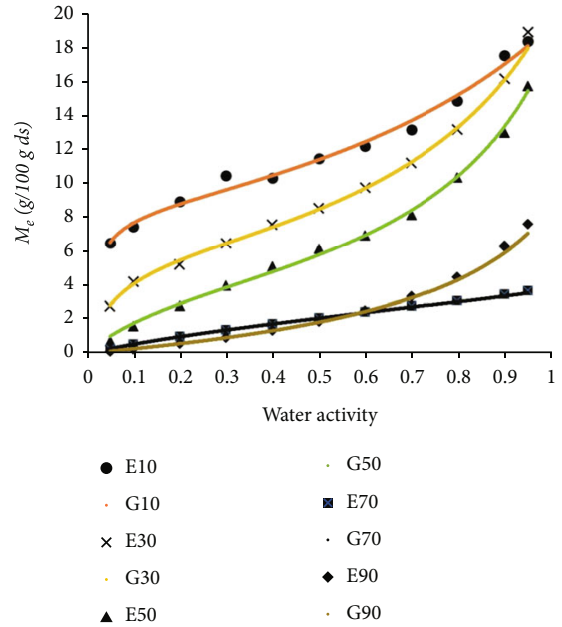

(a)
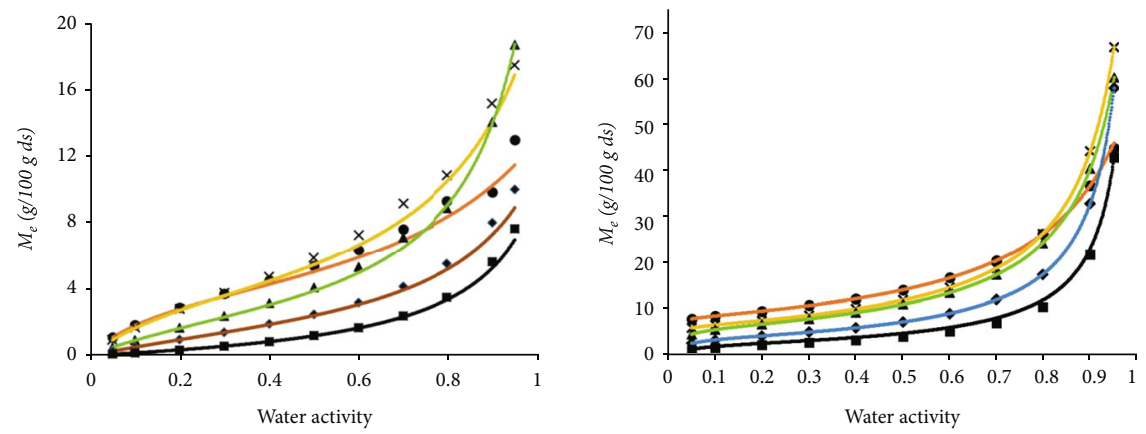

FIGURE 5: Adsorption isotherms of cellulose, lignin, and hemicellulase at temperature from 10 to $90^{\circ} \mathrm{C}$.

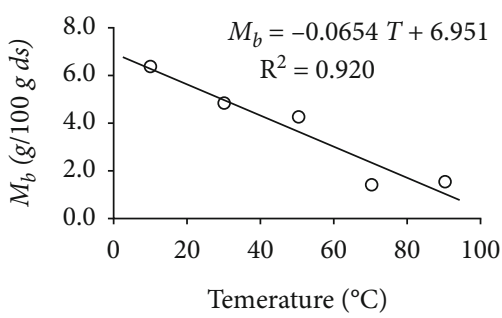

(a)

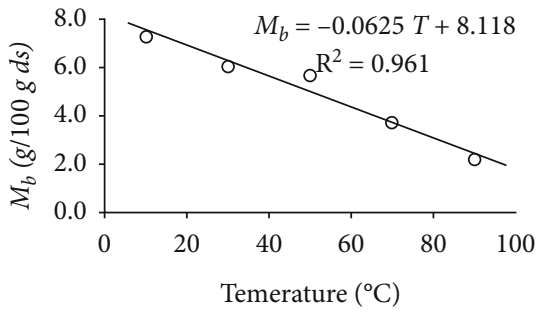

(c)

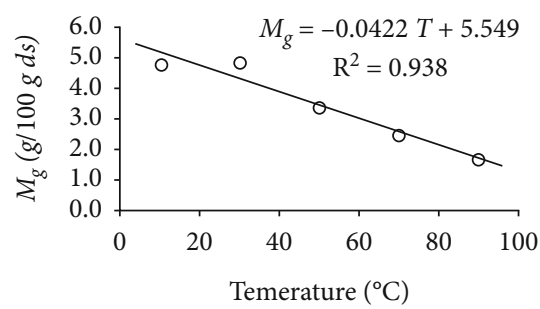

(e)

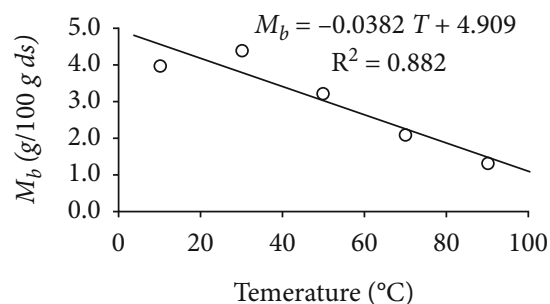

(b)

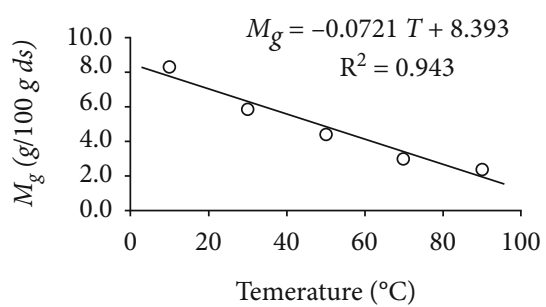

(d)

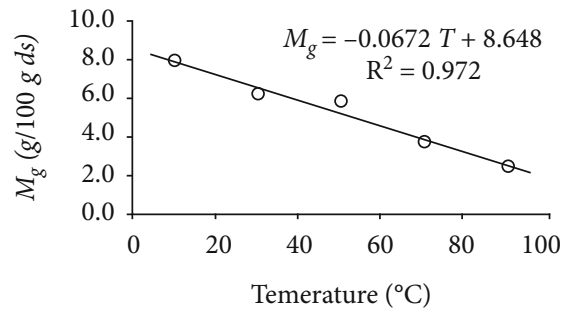

(f)

Figure 6: BET ((a) cellulose, (b) lignin, and (c) hemicellulase) and GAB ((d) cellulose, (e) lignin, and (f) hemicellulase) monolayer values as a function of temperature.

increasing temperature. The values of $B$ were plotted as Arrhenius equation as a function of $1 / T$ (Figures $7(a)-7(\mathrm{c})$ ).

The nonlinear regression was implemented for the GAB model for the whole range of water activity (i.e., 0.05 to 0.95 ) with a regression coefficient $\left(R^{2}\right)$ varied from 0.85 to 0.99 (Table 1). The $M_{g}$ values from the GAB model decreased with the increase of temperature, and it was correlated linearly with temperature (i.e., $R^{2}$ of $0.943,0.938$, and 0.938 for cellulose, lignin, and hemicellulase, respectively) (Figures 6(d)-6(f)). The GAB model was used to predict sorption isotherms of many food products [41, 71, 72], vegetables like dried-onions and green beans [40], and fruit like 


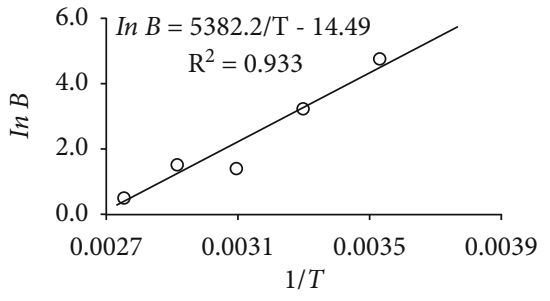

(a)

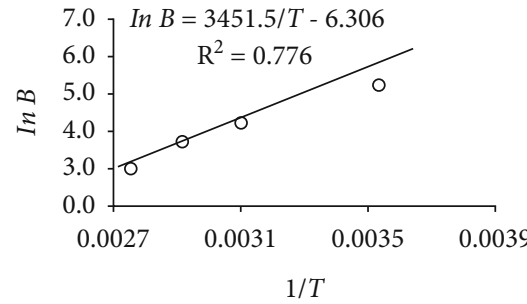

(c)

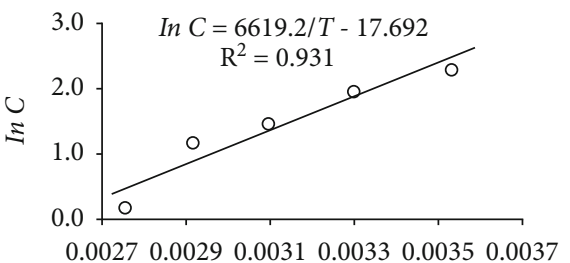

$1 / T$

(e)

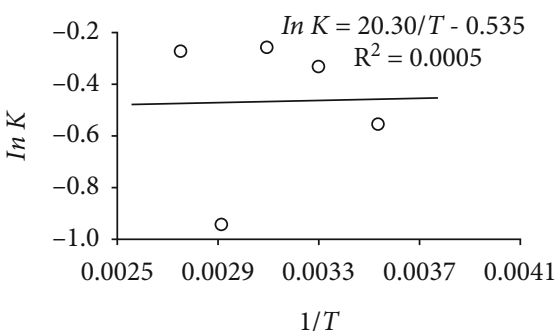

(g)

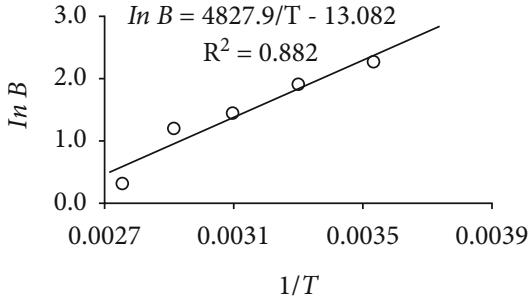

(b)

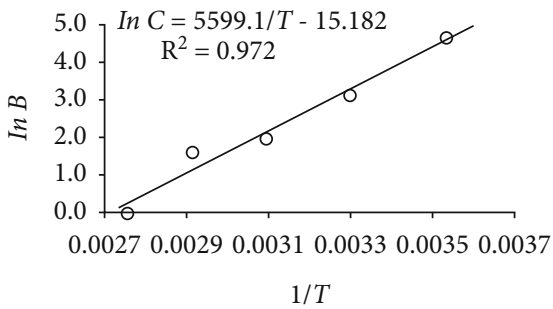

(d)

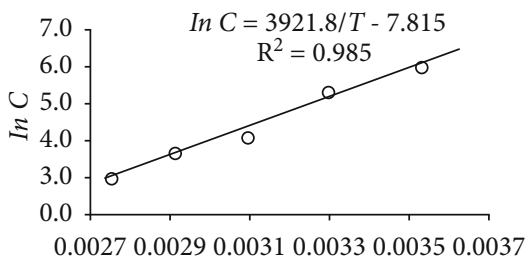

$1 / T$

(f)

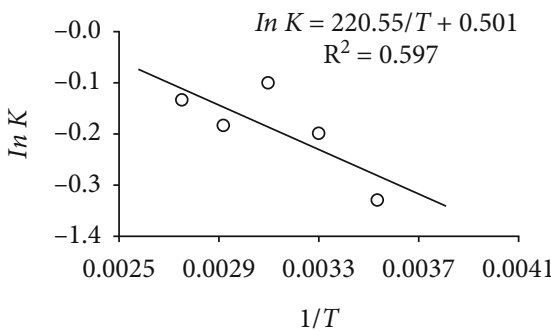

(h)

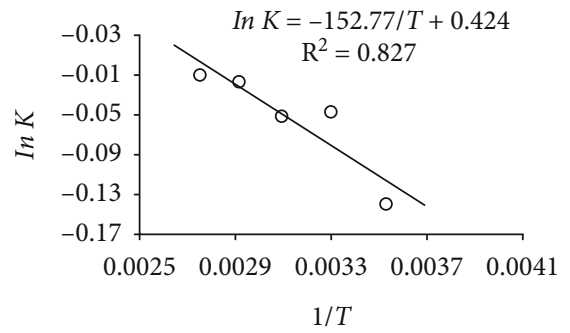

(i)

Figure 7: BET model $B$ values ((a) cellulose, (b) lignin, and (c) hemicellulase), GAB model $C$ values ((d) cellulose, (e) lignin, and (f) hemicellulase), and $K$ values ((g) cellulose, (h) lignin, and (i) hemicellulase) as a function of temperature.

apple, blackcurrant, sour cherries, apricots, and coffee fruit $[73,74]$.

ln $C$ value was plotted as a function of inverse temperature $(1 / T)$, and regression coefficient showed more than 0.9 (Figures $7(\mathrm{~d})-7(\mathrm{f})$ ). However, regression coefficients of $\ln K$ versus $1 / T$ plots showed lower than 0.6 , in the case of cellu- lose and lignin (Figures 7(g)-7(i)). Chirife [75] and Rahman $[8]$ also pointed that $K$ values should be less than unity and less affected by temperature.

3.5. Isosteric Heat of Adsorption. Equation (4) was used to calculate the isosteric heat of adsorption, and it decreased 


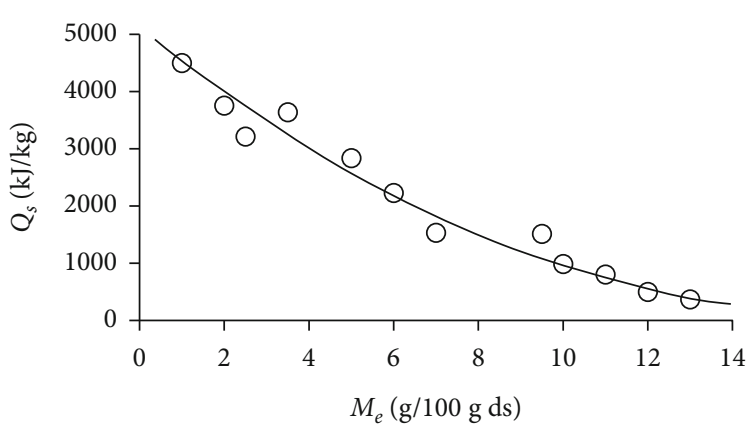

(a)

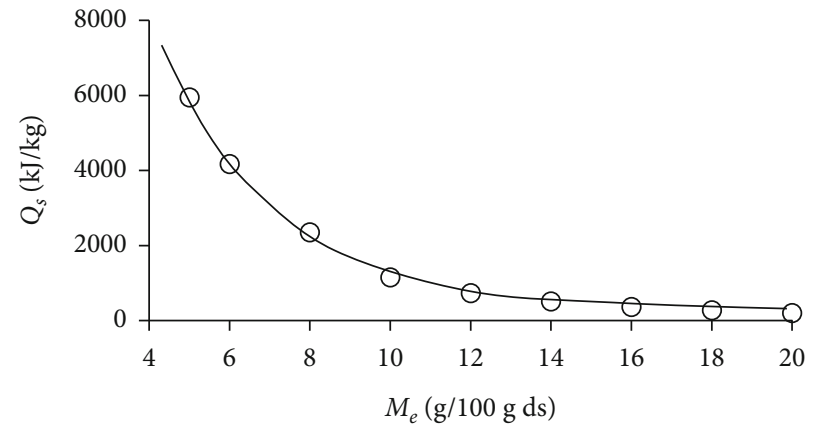

(b)

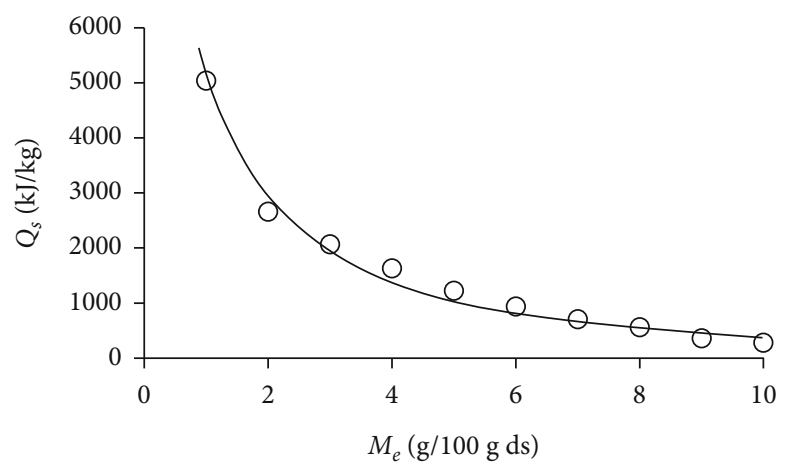

(c)

FIGURE 8: Isosteric heat of adsorption as a function of moisture content ((a) cellulose, (b) lignin, and (c) hemicellulase).

with the increase of moisture (Figure 8). This behaviour was also observed in other studies for quinoa, dried fruit, cassava, orange juice powder, and jasmine rice crackers [62, 66, 76-79]. A steeped increase in heat of sorption was observed below moisture 4.0 to $10.0 \mathrm{~g} / 100 \mathrm{~g}$ sample depending on the sample. This was because water binding energy increased at lower water content [79]. Similar justification was also proposed by other researches $[65,67,80,81]$. Therefore, removal of bound water from the surface can be tougher [76].

\section{Conclusion}

The DTH chamber method showed several advantages over conventional isopiestic method. It showed high reproducibility (i.e., 0.0074 to $7.6 \%$ ) as compared to the conventional isopiestic method (i.e., 0.75 to $21 \%$ ) at different equilibrium relative humidity. In addition, DTH chamber method can be used to achieve quick equilibration time (i.e., $30 \mathrm{~min}$ ); temperature and relative humidity could be selected at any point within the relative humidity 0 to $98 \%$ and temperature from -15 to $100^{\circ} \mathrm{C}$, respectively. The adsorption isotherm of cellulose, lignin, and hemicellulase was measured within the temperature of $10-90^{\circ} \mathrm{C}$ and relative humidity from 5 to $95 \%$. The adsorption isotherm was modelled by BET and GAB models, and these model parameters were correlated with the temperature. At $10^{\circ} \mathrm{C}, \mathrm{BET}$ monolayer values were $6.37,7.28$, and $3.98 \mathrm{~g} / 100 \mathrm{ds}$, respectively, for cellulose, lignin, and hemicellulase.

\section{Data Availability}

Figure and table sections were separated from manuscript and uploaded as a new file under the name "Figures and table," and legends were added at the end of the manuscript.

\section{Consent}

Consent was not necessary.

\section{Disclosure}

This paper has been presented as a poster in the following: Sorption Science Symposium 2021-Online on 22 and 23 September 2021.

\section{Conflicts of Interest}

The authors declare that they have no conflict of interest.

\section{Acknowledgments}

This project was supported by the His Majesty Trust Funds (SR/AGR/FOOD/2019/1) on the valorisation of underutilized food waste.

\section{References}

[1] S. Arntfield, E. Murray, and M. Ismond, "The influence of processing parameters on food protein functionality III. Effect of moisture content on the thermal stability of fababean protein," 
Canadian Institute of Food Science and Technology Journal, vol. 18, no. 3, pp. 226-232, 1985.

[2] M. Mathlouthi, "Water content, water activity, water structure and the stability of foodstuffs," Food Control, vol. 12, no. 7, pp. 409-417, 2001.

[3] V. M. D. Silva, L. A. Silva, J. B. D. Andrade, M. C. Veloso, and G. V. Santos, "Determination of moisture content and water activity in algae and fish by thermoanalytical techniques," Quimica Nova, vol. 31, no. 4, pp. 901-905, 2008.

[4] S. Zhang, N. Kim, W. Yokoyama, and Y. Kim, "Effects of moisture content on mechanical properties, transparency, and thermal stability of yuba film," Food Chemistry, vol. 243, pp. 202207, 2018.

[5] C. Bourlieu, V. Guillard, B. Vallès-Pamiès, S. Guilbert, and N. Gontard, "Edible moisture barriers: how to assess of their potential and limits in food products shelf-life extension?," Critical Reviews in Food Science and Nutrition, vol. 49, no. 5, pp. 474-499, 2009.

[6] M. Eskin and D. S. Robinson, Food Shelf Life Stability: Chemical, Biochemical, and Microbiological Changes, CRC Press, 2000.

[7] M. Rahman, S. Kasapis, N. S. Z. al-Kharusi, I. M. al-Marhubi, and A. Khan, "Composition characterisation and thermal transition of date pits powders," Journal of Food Engineering, vol. 80, no. 1, pp. 1-10, 2007.

[8] M. S. Rahman, Food Properties Handbook, CRC press, 2009.

[9] R. Steele, Understanding and Measuring the Shelf-Life of Food, Woodhead Publishing, 2004.

[10] W. Bousfield, "Iso-piestic solutions," Transactions of the Faraday Society, vol. 13, no. June, pp. 401-410, 1918.

[11] W. Spiess and W. Wolf, "Critical Evaluation of Methods to Determine Moisture Sorption Isotherms," in Water Activity : Theory and Applications to Foods, L. B. Rockland and L. R. Beuchat, Eds., pp. 215-233, Marcel Dekker, New York, 1987.

[12] R. E. Wrolstad, Current Protocols in Food Analytical Chemistry, Wiley, 2001.

[13] M. Shafiur Rahman and R. Hamed al-Belushi, "Dynamic isopiestic method (DIM): measuring moisture sorption isotherm of freeze-dried garlic powder and other potential uses of DIM," International Journal of Food Properties, vol. 9, no. 3, pp. 421-437, 2006.

[14] A. Kirgintsev and L. Trushnikova, "Isopiestic method for determination of solid phases in ternary systems," Zhurnal Neorganicheskoi Khimii, vol. 13, pp. 1146-1148, 1968.

[15] P. Platford, "Isopiestic determination of solubilities in mixed salt solutions; two salt systems," American Journal of Science, vol. 272, no. 10, pp. 959-968, 1972.

[16] A. G. Tereshchenko, "Reflections on factors that affect the duration and accuracy of isopiestic investigations," Journal of Solution Chemistry, vol. 48, no. 3, pp. 354-366, 2019.

[17] J. Zhou, Q.-Y. Chen, Y. Zhou, and Z.-L. Yin, “A new isopiestic apparatus for the determination of osmotic coefficients," The Journal of Chemical Thermodynamics, vol. 35, no. 12, pp. 1939-1963, 2003.

[18] A. Cejkova, "Use of the isopiestic method to determine the osmotic pressure of concentrated nutrient solutions for the cultivation of osmophilic microorganisms," Folia Microbiologia (Praha), vol. 10, pp. 246-250, 1965.

[19] S. Sablani, M. Rahman, and T. Labuza, "Measurement of water activity using isopiestic method," Current Protocols in Food Analytical Chemistry, vol. 1, no. 1, 2001.
[20] S. Gal, "Recent developments in techniques of obtaining complete sorption isotherms," in Water Activity: Influence on Food Quality, L. B. Rockland and G. F. Steward, Eds., pp. 89-111, Spiess, W.E.L. and Wolf, New York, 1981.

[21] G. Scatchard, W. Hamer, and S. Wood, "Isotonic solutions. I. The chemical potential of water in aqueous solutions of sodium chloride, potassium chloride, sulfuric acid, sucrose, urea and glycerol at 25," Journal of the American Chemical Society, vol. 60, no. 12, pp. 3061-3070, 1938.

[22] H. P. Gregor, B. R. Sundheim, K. M. Held, and M. H. Waxman, "Studies on ion-exchange resins. V. Water vapor sorption," Journal of Colloid Science, vol. 7, no. 5, pp. 511-534, 1952.

[23] A. Kirgintsev, G. Kotlyar-Shapirov, and V. Timofeev, "Device for isopiestic," Russian Journal of Physical Chemistry, vol. 45, pp. 2931-2932, 1971.

[24] D. Sinclair, "A simple method for accurate determinations of vapor pressures of solutions," The Journal of Physical Chemistry, vol. 37, no. 4, pp. 495-504, 1933.

[25] R. C. Weatherwax, "A modified isopiestic method for adsorption of water at high relative vapor pressure," Journal of Colloid and Interface Science, vol. 48, no. 3, pp. 518-519, 1974.

[26] A. H. Al-Muhtaseb, W. A. M. McMinn, and T. R. A. Magee, "Water sorption isotherms of starch powders: part 1: mathematical description of experimental data," Journal of Food Engineering, vol. 61, no. 3, pp. 297-307, 2004.

[27] J. A. Barreiro, S. Fernández, and A. J. Sandoval, "Water sorption characteristics of six row barley malt (Hordeum vulgare)," LWT-Food Science and Technology, vol. 36, no. 1, pp. 37-42, 2003.

[28] A. Benado and S. Rizvi, "Thermodynamic properties of water on rice as calculated from reversible and irreversible isotherms," Journal of Food Science, vol. 50, no. 1, pp. 101-105, 1985.

[29] A. S. Cassini, L. D. F. Marczak, and C. P. Z. Noreña, "Water adsorption isotherms of texturized soy protein," Journal of Food Engineering, vol. 77, no. 1, pp. 194-199, 2006.

[30] A. M. Goula, T. D. Karapantsios, D. S. Achilias, and K. G. Adamopoulos, "Water sorption isotherms and glass transition temperature of spray dried tomato pulp," Journal of Food Engineering, vol. 85, no. 1, pp. 73-83, 2008.

[31] T. Iguedjtal, N. Louka, and K. Allaf, "Sorption isotherms of potato slices dried and texturized by controlled sudden decompression," Journal of Food Engineering, vol. 85, no. 2, pp. 180-190, 2008.

[32] S. S. Kim, S. Y. Kim, D. W. Kim, S. G. Shin, and K. S. Chang, "Moisture sorption characteristics of composite foods filled with strawberry jam," LWT-Food Science and Technology, vol. 31, no. 4, pp. 397-401, 1998.

[33] A. Lopez, M. Pique, M. Clop et al., "The hygroscopic behaviour of the hazelnut," Journal of Food Engineering, vol. 25, no. 2, pp. 197-208, 1995.

[34] E. Montes, R. Torres, R. Andrade, O. Perez, J. Marimon, and I. Meza, "Modelado de las isotermas de desorción del ñame (Dioscorea rotundata)," DYNA, vol. 76, pp. 145-152, 2009.

[35] A. Mihranyan, A. P. Llagostera, R. Karmhag, M. Strømme, and R. Ek, "Moisture sorption by cellulose powders of varying crystallinity," International Journal of Pharmaceutics, vol. 269, no. 2, pp. 433-442, 2004.

[36] N. Volkova, V. Ibrahim, R. Hatti-Kaul, and L. Wadsö, "Water sorption isotherms of Kraft lignin and its composites," Carbohydrate Polymers, vol. 87, no. 2, pp. 1817-1821, 2012. 
[37] C. Van den Berg and S. Bruin, "Water activity and its estimation in food systems," in Proceedings Int. Symp. Properties of Water in Relation to Food Quality and Stability, Osaka, 1978.

[38] G. Peng, X. Chen, W. Wu, and X. Jiang, "Modeling of water sorption isotherm for corn starch," Journal of Food Engineering, vol. 80, no. 2, pp. 562-567, 2007.

[39] M. Alamri, A. A. Mohamed, S. Hussain, M. A. Ibraheem, and A. A. Abdo Qasem, "Determination of moisture sorption isotherm of crosslinked millet flour and oxirane using GAB and BET," Journal of Chemistry, vol. 2018, Article ID 2369762, 8 pages, 2018.

[40] C. M. Samaniego-Esguerra, I. F. Boag, and G. L. Robertson, "Comparison of regression methods for fitting the GAB model to the moisture isotherms of some dried fruit and vegetables," Journal of Food Engineering, vol. 13, no. 2, pp. 115-133, 1991.

[41] E. O. Timmermann, J. Chirife, and H. Iglesias, "Water sorption isotherms of foods and foodstuffs: BET or GAB parameters?," Journal of Food Engineering, vol. 48, no. 1, pp. 19-31, 2001.

[42] Binder, 2021, https://www.binder-world.com/en/tips-tricks/ apt-line-preheating-chamber-technology.

[43] P. Sherrod, Nonlinear regression analysis program (NLREG), P. Sherrod, Nashville, TN, 1991.

[44] S. Brunauer, P. H. Emmett, and E. Teller, "Adsorption of gases in multimolecular layers," Journal of the American Chemical Society, vol. 60, no. 2, pp. 309-319, 1938.

[45] T. P. Labuza, "Psorption phenomena in foods," Food Technology, vol. 22, p. 263, 1968.

[46] R. B. Anderson, "Modifications of the Brunauer, Emmett and Teller equation 1," Journal of the American Chemical Society, vol. 68, no. 4, pp. 686-691, 1946.

[47] J. H. Deboer, The dynamical character of adsorption, LWW, 1953.

[48] E. A. Guggenheim, Applications of Statistical Mechanics, Clarendon P, 1966.

[49] N. Shanker, M. M. Kumar, P. Juvvi, and S. Debnath, "Moisture sorption characteristics of ready-to-eat snack food enriched with purslane leaves," Journal of Food Science and Technology, vol. 56, no. 4, pp. 1918-1926, 2019.

[50] N. Aviara, O. Ajibola, and U. Dairo, "PH-postharvest technology: thermodynamics of moisture sorption in sesame seed," Biosystems Engineering, vol. 83, no. 4, pp. 423-431, 2002.

[51] S. Arslan-Tontul, "Moisture sorption isotherm and thermodynamic analysis of quinoa grains," Heat and Mass Transfer, vol. 57, no. 3, pp. 543-550, 2021.

[52] A. Mulet, J. García-Reverter, R. Sanjuán, and J. Bon, “Sorption isosteric heat determination by thermal analysis and sorption isotherms," Journal of Food Science, vol. 64, no. 1, pp. 64-68, 1999.

[53] M. S. Gruszkiewicz and J. M. Simonson, "Vapor pressures and isopiestic molalities of concentrated $\mathrm{CaCl} 2(\mathrm{aq}), \mathrm{CaBr} 2(\mathrm{aq})$, and $\mathrm{NaCl}(\mathrm{aq})$ to $\mathrm{T}=523 \mathrm{~K}$," The Journal of Chemical Thermodynamics, vol. 37, no. 9, pp. 906-930, 2005.

[54] J. A. Rard and R. F. Platford, "Experimental methods: isopiestic," Activity Coefficients in Electrolyte Solutions, vol. 2, pp. 209-277, 1991.

[55] J. A. Rard, R. F. Platford, and K. Pitzer, Activity coefficients in electrolyte solutions, CRC Press, Boca Raton, FL, 1991.

[56] R. Sadeghi and F. Ziamajidi, "Thermodynamic properties of aqueous polypropylene oxide 400 solutions from isopiestic measurements over a range of temperatures," Fluid Phase Equilibria, vol. 249, no. 1, pp. 165-172, 2006.
[57] D. B. Thiessen and A. J. Wilson, "An isopiestic method for measurement of electrolyte activity coefficients," AIChE Journal, vol. 33, no. 11, pp. 1926-1929, 1987.

[58] G. Mikulin, Problems of Physical Chemistry of Electrolyte Solutions, Khimiya, Leningrad, 1968.

[59] H. Park and P. Englezos, "Osmotic coefficient data for $\mathrm{Na} 2 \mathrm{SiO} 3$ and $\mathrm{Na} 2 \mathrm{SiO} 3-\mathrm{NaOH}$ by an isopiestic method and modeling using Pitzer's model," Fluid Phase Equilibria, vol. 153, no. 1, pp. 87-104, 1998.

[60] D. Ž. Popović, J. Miladinović, Z. P. Miladinović, S. R. Grujić, M. D. Todorović, and J. A. Rard, "Isopiestic determination of the osmotic and activity coefficients of the $\{\mathrm{yKBr}+(1-\mathrm{y})$ $\mathrm{K} 2 \mathrm{HPO} 4\}$ (aq) system at T=298.15 K," The Journal of Chemical Thermodynamics, vol. 62, pp. 151-161, 2013.

[61] C. M. Romero, B. Luis, M. E. González, and M. T. Dávila, "Construction and calibration of an isopiestic apparatus for determination of osmotic and activity coefficients," Revista Colombiana de Química, vol. 35, no. 2, pp. 205214, 2006.

[62] U. Siripatrawan and P. Jantawat, "Determination of moisture sorption isotherms of jasmine rice crackers using BET and GAB models," Food Science and Technology International, vol. 12, no. 6, pp. 459-465, 2006.

[63] P. Staudt, C. Kechinski, I. Tessaro, L. Marczak, R. D. P. Soares, and N. Cardozo, "A new method for predicting sorption isotherms at different temperatures using the BET model," Journal of Food Engineering, vol. 114, no. 1, pp. 139-145, 2013.

[64] J. G. Kapsalis, "Influences of Hysteresis and Temperature on Moisture Sorption Isotherms," in Water Activity: Theory and Applications to Food, pp. 173-213, Routledge, 2017.

[65] C. Jorge, Handbook of Food Isotherms: Water Sorption Parameters for Food and Food Components, Food science and technology (USA), 1982.

[66] C. Rohvein, E. Santalla, and M. Gely, "Note: estimation of sorption isotherm and the heat of sorption of quinoa (Chenopodium quinoaWilld.) seeds," Food Science and Technology International, vol. 10, no. 6, pp. 409-413, 2004.

[67] W. McMinn and T. Magee, "Thermodynamic properties of moisture sorption of potato," Journal of Food Engineering, vol. 60, no. 2, pp. 157-165, 2003.

[68] F. Kaymak-Ertekin and A. Gedik, "Sorption isotherms and isosteric heat of sorption for grapes, apricots, apples and potatoes," LWT-Food Science and Technology, vol. 37, no. 4, pp. 429-438, 2004.

[69] A. Vega-Galvez, E. Lara, and R. Lemus-Mondaca, "Isotermas de adsorción en harina de maíz (Zea mays L.)," Ciencia eTecnologiadeAlimentos, vol. 26, no. 4, pp. 821-827, 2006.

[70] A. Vega-Gálvez, J. López, M. Miranda, K. Di Scala, F. Yagnam, and E. Uribe, "Mathematical modelling of moisture sorption isotherms and determination of isosteric heat of blueberry variety O'Neil," International Journal of Food Science \& Technology, vol. 44, no. 10, pp. 2033-2041, 2009.

[71] Z. Maroulis, E. Tsami, D. Marinos-Kouris, and G. Saravacos, "Application of the GAB model to the moisture sorption isotherms for dried fruits," Journal of Food Engineering, vol. 7, no. 1, pp. 63-78, 1988.

[72] E. J. Quirijns, A. J. Van Boxtel, W. K. van Loon, and G. Van Straten, "Sorption isotherms, GAB parameters and isosteric heat of sorption," Journal of the Science of Food and Agriculture, vol. 85, no. 11, pp. 1805-1814, 2005. 
[73] A. Goneli, P. Corrêa, G. D. Oliveira, and P. A. Júnior, "Water sorption properties of coffee fruits, pulped and green coffee," LWT-Food Science and Technology, vol. 50, no. 2, pp. 386391, 2013.

[74] R. Klewicki, D. Konopacka, M. Uczciwek, Z. Irzyniec, E. Piasecka, and C. Bonazzi, "Sorption isotherms for osmoconvectively-dried and osmo-freeze-dried apple, sour cherry, and blackcurrant," The Journal of Horticultural Science and Biotechnology, vol. 84, no. 6, pp. 75-79, 2009.

[75] J. Chirife, E. O. Timmermann, H. A. Iglesias, and R. Boquet, "Some features of the parameter $\mathrm{k}$ of the GAB equation as applied to sorption isotherms of selected food materials," Journal of Food Engineering, vol. 15, no. 1, pp. 75-82, 1992.

[76] M. Edrisi Sormoli and T. A. G. Langrish, "Moisture sorption isotherms and net isosteric heat of sorption for spray-dried pure orange juice powder," LWT-Food Science and Technology, vol. 62, pp. 875-882, 2015.

[77] B. K. Koua, P. M. E. Koffi, P. Gbaha, and S. Toure, "Thermodynamic analysis of sorption isotherms of cassava (Manihot esculenta)," Journal of Food Science and Technology, vol. 51, no. 9, pp. 1711-1723, 2014.

[78] A. Pumacahua-Ramos, J. A. Gomez Vieira, J. Telis-Romero, H. A. Villa-Vélez, and J. F. Lopes Filho, "Isotherms and isosteric heat of sorption of two varieties of Peruvian quinoa," Scientia Agropecuaria, vol. 7, no. 4, pp. 409-417, 2016.

[79] E. Tsami, "Net isosteric heat of sorption in dried fruits," Journal of Food Engineering, vol. 14, no. 4, pp. 327-335, 1991.

[80] E. Ayranci and O. Duman, "Moisture sorption isotherms of cowpea (Vigna unguiculata L. Walp) and its protein isolate at 10, 20 and 30 C," Journal of Food Engineering, vol. 70, no. 1, pp. 83-91, 2005.

[81] E. Palou, A. Lopez-Malo, and A. Argaiz, "Effect of temperature on the moisture sorption isotherms of some cookies and corn snacks," Journal of Food Engineering, vol. 31, no. 1, pp. 85-93, 1997. 